\title{
Eight microsatellite loci characterised in the European blackbird, Turdus merula
}

\author{
Gernot Segelbacher - Thomas Sacher - Anke Schwarzenberger • \\ Sonja Woitsch · Franz Bairlein · Timothy Coppack
}

Received: 24 January 2007/Revised: 10 July 2007 / Accepted: 29 August 2007/Published online: 21 September 2007

(C) Dt. Ornithologen-Gesellschaft e.V. 2007

\begin{abstract}
Although the European blackbird, Turdus merula, is one of the most abundant and conspicuous songbirds of the Western Palaearctic and, as such, has been subject of numerous behavioural and ecological studies, there is to date no specific, PCR-based marker system for this species, and information on the applicability of genetic markers from other species or genera is scant. Here, we report the successful amplification of eight microsatellite loci in the European blackbird. We compared levels of polymorphism between groups of individuals sampled during the breeding season at different geographic localities (Heligoland Island, North Sea and Radolfzell, south-western Germany). We found high levels of polymorphisms, which enabled us to ascertain population membership of individuals. The properties of the tested microsatellite markers make them suitable for population genetic studies as well as for kinship analyses.
\end{abstract}

Communicated by M. Wink.

G. Segelbacher $(\bowtie)$

Vogelwarte Radolfzell, Max Planck Institute for Ornithology,

Schlossallee 2, 78315 Radolfzell, Germany

e-mail: segelbacher@orn.mpg.de

G. Segelbacher

Department of Wildlife Ecology and Management,

University of Freiburg, Tennenbacher Str.4,

79106 Freiburg, Germany

T. Sacher · F. Bairlein - T. Coppack

Institute of Avian Research "Vogelwarte Helgoland",

An der Vogelwarte 21, 26386 Wilhelmshaven, Germany

A. Schwarzenberger $\cdot$ S. Woitsch

University of Constance, Universitätsstraße 10,

78464 Constance, Germany
Keywords Microsatellites - Molecular marker ·

Polymorphism · Population differentiation · Turdus merula

\section{Introduction}

Being able to distinguish between individuals of different origin is central to most ornithological studies, but often this cannot be achieved through ringing and observation alone. The application of molecular genetic markers can help establish population connectivity (Webster et al. 2002; Wink 2006) and has surely revolutionised our view of avian mating systems (Griffith et al. 2002). However, for the majority of species, including the European blackbird, Turdus merula, it seems that the dawn of the molecular age has only just begun.

The European blackbird is one of the most abundant and conspicuous songbirds of the Western Palearctic (Cramp 1988) —and one of the most successful, judged by its ability to adjust to a wide range of environments in many parts of the world (see Kentish et al. 1995; Sol et al. 2002). Since the beginning of the twentieth century, it has rapidly extended its breeding distribution to northern and eastern Europe, colonising habitats along the entire ruralurban gradient (Luniak et al. 1990; Luniak 2004; Stephan 1999). The blackbird has been the focus of several studies concerning the mechanisms that drive behavioural and life-history changes with increasing urbanisation (e.g. Partecke et al. 2004, 2006). But information about the extent of genetic exchange between populations distributed along the rural-urban gradient is still scarce. This information, however, can be decisive in resolving whether or not different ecotypes of the blackbird represent independent genetic entities resulting from local adaptation. 
Microsatellites-simple, non-coding sequence repeats within nuclear DNA-have become the genetic marker of choice for answering questions at the level of individuals and populations, mainly because of their high mutation rate and polymorphism (Webster et al. 2002; Schlötterer 2004). So far, no specific marker system has been developed for the European blackbird, and information about the applicability of genetic markers from other species or genera is scant. In this short communication, we report the successful amplification of eight microsatellite loci in the European blackbird.

\section{Materials and methods}

Genetic variability was examined in a total of 147 blackbirds from two study sites. The first was situated in the surroundings of Radolfzell $\left(47^{\circ} 44^{\prime} \mathrm{N}, 08^{\circ} 58^{\prime} \mathrm{E}\right)$ in southwestern Germany. The second was the island of Heligoland $\left(54^{\circ} 12^{\prime} \mathrm{N}, 07^{\circ} 56^{\prime} \mathrm{E}\right)$ in the North Sea about $50 \mathrm{~km}$ from the German mainland.

DNA was extracted from blackbird feathers or blood samples, using a silica-based column method (Qiagen, Hilden, Germany) following the manufacturer's protocol. PCR amplifications were performed in $10 \mu \mathrm{l}$ reactions in a Perkin-Elmer thermal cycler. Each reaction mix contained $1 \mu \mathrm{l}$ DNA extraction, $2.5 \mathrm{mM} \mathrm{MgCl} 2,25 \mathrm{mM}$ Tris- $\mathrm{HCl}$ (pH 8.0), $35 \mathrm{mM} \mathrm{KCl,} 0.1 \mathrm{mM}$ EDTA, $1 \mathrm{mM}$ DTT, 50\% glycerol, $0.5 \%$ (v/v) Tween-20, 0.5\% IGEPAL CA-630, $0.2 \mathrm{mM}$ of each nucleotide, $5 \mathrm{pmol}$ of each primer) and 0.5 units Taq polymerase (Eppendorf HotmasterTaq; Eppendorf, Hamburg, Germany). PCR profiles consisted of $2 \mathrm{~min}$ denaturation at $94^{\circ} \mathrm{C}, 35$ cycles of $30 \mathrm{~s}$ denaturation at $94^{\circ} \mathrm{C}, 30 \mathrm{~s}$ annealing at the specified temperature and $30 \mathrm{~s}$ extension at $68^{\circ} \mathrm{C}$ with a final $5 \mathrm{~min} 68^{\circ} \mathrm{C}$ step. PCR fragments were resolved by electrophoresis on an ABI 377 sequence analyser.

Allele frequencies and estimates of within-population diversity (observed number of alleles, heterozygosity) and between-population divergence were calculated using FSTAT 2.9.3 (Goudet 1995) and CERVUS (Marshall et al. 1998).

\section{Results and discussion}

High levels of variability could be detected in the analysed loci, with the number of alleles ranging from 4 to 21 per locus (Table 1). Genetic differentiation between the two study sites was high $\left(F_{\mathrm{ST}}=0.135\right)$. The number of alleles was lower in the island than in the mainland population, even after correcting for the considerable difference in sample size (Table 2).

Observed and expected heterozygosity differed significantly in four microsatellite loci $(\mathrm{Cu} \mu 28, \operatorname{Mjg} 1, \operatorname{Pdo} \mu 4$, Pdo $\mu 5)$. However, our samples from Radolfzell comprised a number of siblings collected from the same nests, which may explain these differences; when analysing whole families we found possible null alleles only in locus Pdo $\mu 5$.

Our preliminary analysis shows that the eight tested microsatellite loci are generally suitable for analysing genetic divergence among blackbird populations. We tested a number of other passerine loci, but these did not amplify any PCR product (Lox7, Piertney et al. 1998; Ls1, Mundy and Woodruff 1996; Phtr3, Fridolfsson et al. 1997; Gf5B, Petren 1998; Pca3, Pca9, Dawson et al. 2000) or were monomorphic $(\mathrm{Cu} \mu 4$, Gibbs et al. 1999; Ltr7, Lillandt et al. 2002; Vecr2, Vecr8, Stenzler et al. 2004) in the blackbird. The set of eight polymorphic genetic markers could, for example, be used to estimate the rate of gene flow between migratory and sedentary blackbird populations (Sacher et al. 2006) or to determine the extent to which urban blackbird populations represent distinct and independent genetic entities (see Luniak 2004; Partecke et al. 2006). The presented marker system may also be used for pedigree analyses and paternity testing. We eagerly await the first biological results from its application.

Table 1 Characterisation of eight polymorphic microsatellite loci for the blackbird Turdus merula, originally isolated from other passerine species. $T_{\mathrm{a}}$ Annealing temperature, $n$ number of individuals tested, $A$ number of alleles, $H_{O}$ observed heterozygosity, $H_{E}$ expected heterozygosity

\begin{tabular}{|c|c|c|c|c|c|c|c|}
\hline Locus & Original reference & EMBL accession number & $T_{\mathrm{a}}\left({ }^{\circ} \mathrm{C}\right)$ & $n$ & $A$ & $H_{\mathrm{O}}$ & $H_{\mathrm{E}}$ \\
\hline $\mathrm{Cu} \mu 28$ & Gibbs et al. (1999) & AF122895 & 57 & 139 & 16 & 0.69 & 0.90 \\
\hline Lox 1 & Piertney et al. (1998) & Y16820 & 55 & 145 & 4 & 0.59 & 0.58 \\
\hline Ltmr 6 & McDonald and Potts (1994) & none & 58 & 133 & 14 & 0.80 & 0.88 \\
\hline Mjg 1 & Li et al. (1997) & U82673 & 54 & 133 & 21 & 0.55 & 0.89 \\
\hline Pat 43 & Otter et al. (1998) & none & 59 & 138 & 21 & 0.83 & 0.89 \\
\hline $\operatorname{Pdo} \mu 4$ & Neumann et al. (1996) & AM287191 & 56 & 133 & 11 & 0.59 & 0.77 \\
\hline $\operatorname{Pdo} \mu 5$ & Griffith et al. (1999) & Y15126 & 55 & 95 & 24 & 0.60 & 0.92 \\
\hline Z1104 & Degnan et al. (1999) & AF076665 & 59 & 142 & 5 & 0.65 & 0.65 \\
\hline
\end{tabular}


Table 2 Genetic diversity of two blackbird populations from Radolfzell and Heligoland (Germany). AR Allelic richness

\begin{tabular}{lrrrrr}
\hline Location & \multicolumn{1}{c}{$n$} & \multicolumn{1}{c}{$A$} & $\mathrm{AR}$ & $H_{\mathrm{O}}$ & $H_{\mathrm{E}}$ \\
\hline Radolfzell & 133 & 13.0 & 4.0 & 0.59 & 0.71 \\
Heligoland & 14 & 4.5 & 3.1 & 0.57 & 0.55 \\
\hline
\end{tabular}

\section{Zusammenfassung}

\section{Acht Mikrosatelliten-Loci für die Amsel, Turdus} merula

Obwohl die Amsel, Turdus merula, einer der häufigsten und auffälligsten Singvögel der westlichen Paläarktis darstellt und somit bereits Gegenstand zahlreicher, verhaltensökologischer Untersuchungen war, lag bislang für diese Art kein spezifisches, molekulargenetisches MarkerSystem vor, und Information über die Anwendbarkeit von an anderen Arten entwickelten Markern fehlte weitgehend. Hier berichten wir von der erfolgreichen Amplifizierung von acht variablen Mikrosatelliten-Loci bei der Amsel und vergleichen Ergebnisse zwischen Individuen, die zur Brutzeit in unterschiedlichen Gebieten beprobt wurden (Helgoland, Nordsee und Radolfzell, SW-Deutschland). Wir fanden einen hohen Polymorphismusgrad, der uns ermöglichte, die Populationszugehörigkeit von Individuen eindeutig zu bestimmen. Die getesteten MikrosatellitenMarker eignen sich demzufolge sowohl für populationsgenetische Studien als auch für Verwandtschaftsanalysen.

Acknowledgements This work was supported by the Deutsche Forschungsgemeinschaft (DFG).

\section{References}

Cramp S (1988) Birds of the Western Palearctic, vol 5. Oxford University Press, Oxford

Dawson DA, Hanotte O, Greig C, Stewart IRK, Burke T (2000) Polymorphic microsatellites in the blue tit Parus caeruleus and their cross-species utility in 20 songbird families. Mol Ecol 9:1941-1944

Degnan SM, Robertson BC, Clegg SM, Moritz CC (1999) Microsatellite primers for studies of gene flow and mating systems in white-eyes (Zosterops). Mol Ecol 8:159-160

Fridolfsson A, Gyllensten UB, Jakobsson S (1997) Microsatellite markers for paternity testing in the Willow warbler Phylloscopus trochilus: high frequency of extra-pair young in an island population. Hereditas 126:127-132

Gibbs HL, Tabak LM, Hobson K (1999) Characterization of microsatellite DNA loci for a neotropical migrant songbird the Swainson's thrush (Cathurus ustulatus). Mol Ecol 8:1551-1552

Goudet J (1995) Fstat version 1.2: a computer program to calculate F-statistics. J Hered 86:485-486

Griffith SC, Owens IPF, Burke T (1999) Female choice and annual reproductive success favour less-ornamented male house sparrows. Proc R Soc Lond B 266:765-770
Griffith SC, Owens IPF, Thuman KA (2002) Extra pair paternity in birds: a review of interspecific variation and adaptive function. Mol Ecol 11:2195-2212

Kentish BJ, Dann P, Lowe KW (1995) Breeding biology of the common blackbird Turdus merula in Australia. Emu 95:233-244

Li SH, Huang YJ, Brown JL (1997) Isolations of tetranucleotide microsatellites from the Mexican jay Aphelocoma ultramarina. Mol Ecol 6:499-501

Lillandt B-G, Bensch S, Hansson B, Wennerberg L, von Schantz T (2002) Isolation and cross-species amplification of microsatellite loci in the Siberian Jay (Perisoreus infaustus). Hereditas 137:157-160

Luniak M (2004) Synurbization-adaptation of animal wildlife to urban development. In: Shaw WW, Harris LK, Vandruff L (eds) Proceedings of the 4th international symposium on urban wildlife conservation, Tucson, Arizona, pp 50-55

Luniak M, Mulsow R, Walasz K (1990) Urbanization of the European Blackbird expansion and adaptations of urban population. In: Luniak M (ed) Urban ecological studies in Central and Eastern Europe. Ossolineum, Warsaw, pp 87-199

Marshall TC, Slate J, Kruuk LEB, Pemberton JM (1998) Statistical confidence for likelihood-based paternity inference in natural populations. Mol Ecol 7:39-655

McDonald DB, Potts WK (1994) Cooperative display and relatedness among males in a lek-mating bird. Science 266:1030-1032

Mundy NI, Woodruff DS (1996) Polymorphic microsatellite markers in the loggerhead shrike Lanius ludovicianus isolated from a library enriched for CA repeats. Mol Ecol 5:811-814

Neumann K, Wetton JH (1996) Highly polymorphic microsatellites in the house sparrow Passer domesticus. Mol Ecol 5:307-309

Otter K, Ratcliffe L, Michaud D (1998) Do female black-capped chickadees prefer high-ranking males as extra-pair partners? Behav Ecol Sociobiol 43:25-36

Partecke J, Van't Hof T, Gwinner E (2004) Differences in the timing of reproduction between urban and forest European blackbirds (Turdus merula): result of phenotypic flexibility or genetic differences? Proc R Soc Lond B 271:1995-2001

Partecke J, Gwinner E, Bensch S (2006) Is urbanisation of European blackbirds (Turdus merula) associated with genetic differentiation? J Ornithol 147:549-552

Petren K (1998) Microsatellite primers from Geospiza fortis and cross-species amplification in Darwin's finches. Mol Ecol 7:1771-1788

Piertney SB, Marquiss M, Summers R (1998) Characterization of tetranucleotide microsatellite markers in the Scottish crossbill (Loxia scotia). Mol Ecol 7:1247-1263

Sacher T, Engler J, Gorschewski A, Gottschling M, Hesler N, Bairlein F, Coppack T (2006) Die Helgoländer Amselpopulation: ein Modell für Populationsgenetik und Zugbiologie. Ornithol Jahresber Helgoland 16:76-84

Schlötterer C (2004) The evolution of molecular markers-just a matter of fashion? Nat Rev Genet 5:63-69

Sol D, Timmermans S, Lefebvre L (2002) Behavioural flexibility and invasion success in birds. Anim Behav 63:495-502

Stenzler LM, Fraser R, Lovette IJ (2004) Isolation and characterization of 12 microsatellite loci from Golden-winged Warblers (Vermivora chrysoptera) with broad cross-taxon utility in emberizine songbirds. Mol Ecol Notes 4:602-604

Stephan B (1999) Die Amsel. Neue Brehm-Bücherei 95, Westarp Wissenschaften, Hohenwarsleben

Webster MS, Marra PP, Haig SM, Bensch S, Holmes RT (2002) Links between worlds: unraveling migratory connectivity. Trends Ecol Evol 17:76-83

Wink M (2006) Use of DNA markers to study bird migration. J Ornithol 147:234-244 